\title{
THE EFFECT PROBLEM-BASED LEARNING MODEL ON PROBLEM-SOLVING ABILITY MATHEMATICS STUDENT CLASS IX SMP NEGERI 6 MEDAN
}

\author{
Elfrida Monika Yulianti Sinaga ${ }^{1}$, Ani Minarni ${ }^{2}$ \\ Fakultas Matematika dan Ilmu Pengetahuan Alam, Universitas Negeri Medan \\ Email: selfridamonika@yahoo.com
}

\begin{abstract}
This research is an experiment research that aims to determine the significant effect of problembased learning model on mathematic problem solving ability of grade IX students of SMP Negeri 6 Medan. The population in this study is the entire class IX SMP Negeri 6 Medan consisting of 11 classes. Sampling is done randomly by simple random sampling method and many samples in this research consist of 2 classes, that is class IX-J as control class with conventional learning that is direct learning model and class $I X-K$ as experiment class with problem-based learning model, the number of students in each class is 36 students. The instrument used in this study is a test description of 3 test problem math problem solving abilities that have been declared valid. Based on the test data of mathematical problem solving ability, the average value in the control class is 51.83, while the average value in the experimental class is 75.50. By using the calculation of one-way hypothesis test, obtained at 6.86 and 1.66691 at the real level $=0.05$ so. Thus rejected and accepted, it means there is a significant effect of problem-based learning model of mathematical problem solving ability of students of class IX SMP Negeri 6 Medan.
\end{abstract}

Keyword: mathematics problem solving ability, problem based learning model

\section{PENGARUH MODEL PEMBELAJARAN BERBASIS MASALAH TERHADAP KEMAMPUAN PEMECAHAN MASALAH MATEMATIK SISWA KELAS IX SMP NEGERI 6 MEDAN}

\begin{abstract}
ABSTRAK
Penelitian ini merupakan penelitian eksperimen yang bertujuan untuk mengetahui pengaruh yang signifikan model pembelajaran berbasis masalah terhadap kemampuan pemecahan masalah matematik siswa kelas IX SMP Negeri 6 Medan. Populasi dalam penelitian ini adalah seluruh kelas IX SMP Negeri 6 Medan yang terdiri dari 11 kelas. Pengambilan sampel dilakukan secara acak dengan metode simple random sampling dan banyak sampel dalam penelitian ini terdiri dari 2 kelas, yaitu kelas IX-J sebagai kelas kontrol dengan pembelajaran konvensional yaitu model pembelajaran langsung dan kelas IX-K sebagai kelas eksperimen dengan model pembelajaran berbasis masalah, jumlah siswa pada masing-masing kelas adalah 36 orang siswa. Instrumen yang digunakan dalam penelitian ini adalah tes uraian sebanyak 3 soal tes kemampuan pemecahan masalah matematik yang telah dinyatakan valid. Berdasarkan data tes kemampuan pemecahan masalah matematik, nilai rata-rata di kelas kontrol sebesar 51,83, sedangkan nilai rata-rata di kelas eksperimen sebesar 75,50. Dengan menggunakan
\end{abstract}

Elfrida Monika Yulianti Sinaga, Ani Minarn. The Effect Problem-Based Learning Model on ProblemSolvin Ability Mathematics Student Class IX SMP Negeri 6 Medan. Jurnal Inspiratif, Vol 3. No. 3 Desember 2017. 
perhitungan uji hipotesis satu arah, diperoleh $t_{\text {hitung }}$ sebesar 6,86 dan $t_{\text {tabal }}$ sebesar 1,66691 pada taraf nyata $\alpha=0,05$ sehingga $t_{\text {hitung }}>t_{\text {tablel }}$. Dengan demikian $H_{0}$ ditolak dan $H_{a}$ diterima, artinya terdapat pengaruh yang signifikan model pembelajaran berbasis masalah terhadap kemampuan pemecahan masalah matematik siswa kelas IX SMP Negeri 6 Medan.

\section{Kata kunci: kemampuan pemecahan masalah matematik, model pembelajaran} berbasis masalah

\section{PENDAHULUAN}

\section{Latar Belakang}

National Council of Teachers of Mathematics (NCTM, 2000) menyatakan bahwa ada beberapa aspek yang termasuk dalam kemampuan berpikir matematika salah satunya yaitu pemecahan Masalah (Problem Solving) yang merupakan bagian tak terpisahkan dari semua pembelajaran matematika. Pentingnya mengajarkan pemecahan masalah menurut Cooney (dalam Hudojo, 2005) adalah mengajar siswa untuk menyelesaikan masalah-masalah memungkinkan siswa itu menjadi lebih analitik di dalam mengambil keputusan di dalam kehidupan.

Pemecahan masalah merupakan bagian dari kurikulum matematika yang sangat penting karena dalam proses pembelajaran maupun penyelesaiannya, siswa dimungkinkan untuk memperoleh pengalaman menggunakan pengetahuan serta keterampilan yang sudah dimiliki. Bagi siswa, pemecahan masalah haruslah dipelajari. Pentingnya pemecahan masalah ini juga diungkapkan oleh Beigie (dalam Surya, Putri \& Mukhtar, 2017) bahwa melalui pemecahan masalah, siswa dapat belajar tentang memperdalam pemahaman mereka tentang konsep-konsep matematika dengan bekerja melalui isu-isu yang dipilih dengan hati-hati yang menggunakan aplikasi matematika untuk masalah nyata.

Salah satu langkah yang bisa dilakukan oleh guru sebagai pembimbing peserta didik adalah memilih model pembelajaran yang tepat. Penggunaan model pembelajaran yang kurang tepat dapat menimbulkan kebosanan, kurang paham terhadap materi yang diajarkan dan akhirnya dapat menurunkan motivasi peserta didik dalam belajar. Hal ini sejalan dengan temuan Surya (2013) yakni faktor guru, antara lain : a) masih ada guru yang pendidikannya tidak sesuai dengan mata pelajaran, b) penguasaan guru terhadap materi matematika yang diajarkan masih sangat rendah. Hal ini dapat dilihat dari hasil probing tes guru yang menunjukkan masih terdapat guru yang hanya menguasai $40 \%$ dari tes probing yang dilakukan, c) Guru kurang menguasai materi pembelajaran secata menyeluruh. Hal ini berdasarkan masukan dari angket siswa yang menyatakan bahwa siswa sulit memahami pelajaran yang diberikan guru. Guru seharusnya melibatkan siswa secara aktif dalam belajar tidak hanya ceramah. Guru sebaiknya menggunakan fasilitas dan sumber belajar yang lebih baik lagi dan guru sebaiknya memperbaiki cara mengajar, d) Model pembelajaran yang digunakan guru matematika masih belum bervariasi umumnya guru mengajar dengan metode ceramah. Kemampuan pedagogik guru juga masih minim, kegiatan pembelajaran yang dilakukan masih konvensional, siswa hanya pasif sebagai pendengar. Pembelajaran umumnya satu arah dimana guru memberikan atau menyalin materi atau rumus-rumus, memberikan contoh soal matematika dan dilanjutkan dengan tugas di kelas atau di rumah

Salah satu model pembelajaran yang digunakan adalah model Pembelajaran Berbasis Masalah. Model Pembelajaran Berbasis Masalah merupakan salah satu model pembelajaran yang dapat memberikan kondisi belajar aktif kepada siswa. Melibatkan siswa untuk memecahkan suatu masalah melalui tahap-tahap metode ilmiah sehingga siswa dapat mempelajari pengetahuan yang berhubungan dengan masalah tersebut dan

Elfrida Monika Yulianti Sinaga, Ani Minarn. The Effect Problem-Based Learning Model on ProblemSolvin Ability Mathematics Student Class IX SMP Negeri 6 Medan. Jurnal Inspiratif, Vol 3. No. 3 Desember 2017. 
sekaligus memiliki keterampilan untuk memecahkan masalah.

Sebab menurut Barrow (dalam Huda, 2014) "pembelajaran berbasis masalah sebagai pembelajaran yang diperoleh melalui proses menuju pemahaman akan resolusi suatu masalah". Adapun manfaat bagi peserta didik melalui pembelajaran berbasis masalah menurut Agustina, $d k k$. (2014) yaitu:

(1) dapat beradaptasi dengan perubahan,

(2) dapat bernalar dan berhadapan dengan masalah,

(3) membiasakan bersikap empati, bekerja sama dan menghargai orang lain,

(4) mengidentifikasi kelemahan dan kekuatan sendiri,

(5) memelihara suatu pembelajaran dengan terbuka, kritis dan aktif.

Sulistyani dan Retnawati (2015) dalam penelitiannya bahwa dalam Pembelajaran Berbasis Masalah, aktivitas belajar siswa tampak lebih mengemuka daripada kegiatan guru mengajar pada materi bangun ruang sisi lengkung. Umumnya peserta didik menunjukkan semangat dan ketekunan dalam menyelesaikan masalah, aktif berdiskusi dan saling membantu dalam kelompok.

Berdasarkan uraian di atas, tampak jelas bahwa pembelajaran dengan model Pembelajaran Berbasis Masalah dimulai dengan adanya masalah, kemudian siswa memperdalam pengetahuannya tentang apa yang mereka ketahui untuk memecahkan masalah tersebut. Dalam pembelajaran ini masalah-masalah yang dijadikan sebagai fokus pembelajaran dapat diselesaikan siswa melalui kerja kelompok sehingga dapat memberi pengalaman-pengalaman belajar yang beragam pada siswa seperti kerjasama dan interaksi dalam kelompok, disamping pengalaman belajar yang berhubungan dengan pemecahan masalah seperti membuat hipotesis, merancang percobaan, melakukan penyelidikan, mengumpulkan data, mengintepretasi data, membuat kesimpulan, mempresentasikan, berdiskusi dan membuat laporan.

\section{METODE}

Jenis penelitian ini adalah eksperimen. Penelitian ini melibatkan dua kelas sampel yaitu kelas eksperimen dan kelas kontrol.

\section{Populasi dan Sampel}

Populasi dalam penelitian ini adalah seluruh siswa kelas IX SMP Negeri 6 Medan Tahun Ajaran 2017/2018 yang berjumlah 396 siswa yang tersebar dalam sebelas kelas. Pemilihan sampel dalam penelitian ini dilakukan dengan menggunakan metode simple random sampling yaitu sebuah metode untuk memilih $n$ unit dari $N$ sehingga setiap elemen dari sampel yang berbeda mempunyai kesempatan yang sama untuk dipilih (Cochran, 1991). Dari sebelas kelas IX di SMP Negeri 6 Medan dipilih sampel sebanyak dua kelas, yaitu kelas IX-K untuk kelas eksperimen dengan jumlah siswa-siswanya sebanyak 36 orang yang diajarkan dengan model pembelajaran berbasis masalah dan kelas IX-J untuk kelas kontrol dengan jumlah siswa-siswanya sebanyak 36 orang yang diajarkan dengan pembelajaran konvensional yaitu model pembelajaran langsung.

Rancangan penelitian ini dapat digambarkan sebagai berikut:

Tabel 1 Rancangan Penelitian

\begin{tabular}{|l|c|c|}
\hline \multicolumn{1}{|c|}{ Kelas } & Perlakuan & Tes \\
\hline Kontrol & $\mathrm{X}_{1}$ & $\mathrm{~T}$ \\
\hline Eksperimen & $\mathrm{X}_{2}$ & $\mathrm{~T}$ \\
\hline
\end{tabular}

menggunakan teknik tes. Tes berbentuk uraian

Kelas kontrol diberikan model dengan indikator kemampuan pemecahan pembelajaran langsung, sedangkan kelas masalah matematik siswa.

eksperimen diberikan model pembelajaran Sebelum digunakan sebagai instrumen berbasis masalah. Teknik pengumpulan data tes, terlebih dahulu soal diujicobakan,

Elfrida Monika Yulianti Sinaga, Ani Minarn. The Effect Problem-Based Learning Model on ProblemSolvin Ability Mathematics Student Class IX SMP Negeri 6 Medan. Jurnal Inspiratif, Vol 3. No. 3 Desember 2017. 
sehingga soal layak dijadikan sebagai validitas dan reliabilitas. instrument utama. Uji coba soal meliputi

Tabel 2. Hasil Analisis Instrumen Tes

\begin{tabular}{|c|c|c|}
\hline No Soal & Validitas & \multirow{2}{*}{ Reliabilitas } \\
\hline 1 & Valid & \multirow{2}{*}{ Reliabel } \\
\hline 2 & Valid & \\
\hline 3 & Valid & \\
\hline 4 & Valid & \\
\hline
\end{tabular}

Berdasarkan hasil analisis instrumen tes, tes kemampuan pemecahan masalah matematik siswa dapat digunakan.

\section{HASIL PENELITIAN}

Penelitian tentang kemampuan pemecahan masalah matematik siswa dilakukan di kelas IX-J yang terdiri dari 36 siswa dan di kelas IX-K yang terdiri dari 36 siswa di SMP Negeri 6 Medan. Di kelas IX-J sebagai kelas kontrol dilaksanakan pembelajaran konvensional yaitu model pembelajaran langsung dan di kelas IX-K sebagai kelas eksperimen diberlakukan model pembelajaran berbasis masalah.
Materi yang diajarkan dalam penelitian ini adalah Bangun Ruang Sisi Lengkung yaitu Tabung. Penelitian ini dilakukan sebanyak 3 kali pertemuan dengan rincian 2 kali pertemuan untuk memberi perlakuan dan 1 kali pertemuan untuk memberi tes kemampuan pemecahan masalah matematik. Instrumen penelitian yang digunakan dalam penelitian ini adalah tes kemampuan pemecahan masalah matematik, yang terdiri dari 3 soal berbentuk uraian yang mencakup semua indikator pemecahan masalah.

Berdasarkan deskripsi data tes kemampuan pemecahan masalah matematik siswa diperoleh data siswa sebagai berikut:

\section{Analisis Kemampuan Pemecahan Masalah Matematik Siswa}

Tabel 3. Deskripsi Kemampuan Pemecahan Masalah Matematik Siswa

\begin{tabular}{|l|c|c|}
\hline \multicolumn{1}{|c|}{ Statistik } & Kontrol & Eksperimen \\
\hline Banyak sampel & 36 & 36 \\
\hline Nilai tertinggi & 73,33 & 100 \\
\hline Nilai terendah & 6,67 & 46,67 \\
\hline Mean & 51,83 & 75,50 \\
\hline Standar deviasi & 16,38 & 12,66 \\
\hline
\end{tabular}

kelas kontrol memperoleh nilai rata-rata

Dari Tabel 3, tampak bahwa nilai-nilai tes sebesar 51,83 dan kelas eksperimen kedua kelas berbeda. Dilihat dari rata-rata, memperoleh nilai rata-rata sebesar 75,50. 
Tabel 4 Hasil Uji Normalitas Data

\begin{tabular}{|c|c|c|c|c|}
\hline \multirow{2}{*}{ Kelas } & \multirow{2}{*}{$N$} & \multicolumn{3}{|c|}{$\begin{array}{c}\text { Tes Kemampuan } \\
\text { Pemecahan Masalah } \\
\text { Matematik Siswa }\end{array}$} \\
\cline { 3 - 5 } & & $\chi^{2}{ }_{\text {hitung }}^{2}$ & $\chi^{2}{ }_{\text {tabel }}$ & Ket \\
\hline Kontrol & 36 & 5,23 & 11,3 & Normal \\
\hline Eksper & 36 & 5,40 & 11,3 & Normal \\
\hline
\end{tabular}

Dari Tabel 4, uji normalitas data tes kemampuan pemecahan masalah matematik siswa kelas kontrol diperoleh $\chi^{2}$ hitung $(5,2368)<\chi_{\text {tabel }}^{2}(11,3)$ dan data tes kemampuan pemecahan masalah matematik siswa kelas eksperimen diperoleh $\chi^{2}$ hitung $(5,4035)<\chi_{\text {tabel }}^{2}(11,3)$. Dengan demikian dapat disimpulkan bahwa data tes kemampuan pemecahan masalah matematik siswa memiliki sebaran data yang berdistribusi normal.

Tabel 5 Data Hasil Uji Homogenitas

\begin{tabular}{|c|c|c|c|c|}
\hline $\begin{array}{c}\text { Var } \\
\text { Max }\end{array}$ & $\begin{array}{c}\text { Var } \\
\text { Min }\end{array}$ & $F_{\text {hitung }}$ & $F_{\text {tabel }}$ & Ket \\
\hline 268,34 & 160,20 & $\begin{array}{c}1,67 \\
5\end{array}$ & 1,73 & Sama \\
\hline
\end{tabular}

Karena $F_{\text {hitung }}<F_{\text {tabel }}$ maka $H_{0}$ diterima, artinya kedua kelas memiliki varians yang sama atau homogen.

Berdasarkan hasil uji persyaratan analisis, yaitu pengujian analisis untuk kenormalan distribusi ternyata sampel berdistribusi normal kemudian dilakukan uji homogenitas dan hasilnya kehomogenan varians populasi ternyata terpenuhi. Pengujian hipotesis yang digunakan adalah uji $t$, dengan kriteria pengujian yaitu jika $t_{\text {hitung }}<t_{\text {tabel }}$ maka $H_{o}$ diterima dan $H_{a}$ ditolak pada taraf kepercayaan $95 \%$ dan taraf signifikan $\alpha=$ 0,05 . Hasil pengujian pada taraf nyata $\alpha=$ 0,05 dan $d k=36+36-2=70$ diperoleh $t_{\text {tabel }}=1,66691$. Berdasarkan perhitungan uji hipotesis diperoleh $t_{\text {hitung }}=6,86$ sehingga $H_{0}$ ditolak dan $H_{a}$ diterima yang artinya bahwa terdapat pengaruh yang signifikan model pembelajaran berbasis masalah terhadap kemampuan pemecahan masalah matematik siswa kelas IX SMP Negeri 6 Medan.

\section{PEMBAHASAN}

Berdasarkan pengujian hipotesis menggunakan uji-t dapat disimpulkan bahwa terdapat pengaruh yang signifikan model pembelajaran berbasis masalah terhadap kemampuan pemecahan masalah matematik siswa kelas IX SMP Negeri 6 Medan.. Penelitian ini dilakukan di sekolah yang tidak ada pengklasifikasian kelas (perbedaan kelas antar siswa pintar dengan siswa kurang pintar).

Penelitian di kelas kontrol pada pertemuan pertama, siswa tidak aktif dalam pembelajaran, kurang memahami materi bahkan mengalami kesulitan dalam memecahkan masalah pada LKS yang diberikan. Pada pertemuan berikutnya pun demikian, siswa semakin terlihat tidak peduli dengan pembelajaran sehingga kurang memahami materi dan kesulitan dalam memecahkan masalah pada LKS yang diberikan. Berbeda dengan kelas kontrol, penelitian di kelas eksperimen pada pertemuan pertama, kebanyakan siswa masih merasa asing dengan pembelajaran berbasis

Elfrida Monika Yulianti Sinaga, Ani Minarn. The Effect Problem-Based Learning Model on ProblemSolvin Ability Mathematics Student Class IX SMP Negeri 6 Medan. Jurnal Inspiratif, Vol 3. No. 3 Desember 2017. 
masalah, mereka masih kurang memahami dalam prosedur pengerjaan LAS, masih kurang dalam bekerja sama dengan kelompoknya, dan belum aktif dalam mengeluarkan pendapat pribadi. Pada pertemuan kedua, terlihat respon siswa yang semakin membaik terhadap pembelajaran berbasis masalah, mereka sudah mulai memahami prosedur pengerjaan LAS, kerja sama dalam kelompok membaik, dan semakin aktif dalam mengeluarkan pendapat secara individu.

Hasil tes kemampuan pemecahan masalah matematik siswa kelas kontrol diperoleh pada soal pertama, ada 27 orang memahami masalah $100 \%$, ada 7 orang memahami masalah $66,67 \%$, ada 1 orang memahami masalah $33,33 \%$, dan ada 1 orang tidak memahami masalah sama sekali. Hanya 1 orang yang mampu merencanakan masalah $100 \%$, hanya 10 orang yang mampu merencanakan penyelesaian 50\%, bahkan ada 25 orang yang tidak mampu merencanakan masalah sama sekali. Hanya 1 orang yang mampu melaksanakan penyelesaian $100 \%$, hanya 2 orang yang mampu melaksanakan penyelesaian $66,67 \%$, hanya 5 orang yang mampu melaksanakan penyelesaian $33,33 \%$, bahkan ada 28 orang yang tidak mampu melaksanakan penyelesaian sama sekali. Tidak ada yang melakukan $100 \%$ pengecekan terhadap semua langkah yang dikerjakan, hanya 2 orang yang melakukan 50\% pengecekan terhadap semua langkah yang dikerjakan, bahkan ada 34 orang yang sama sekali tidak melakukan pengecekan terhadap semua langkah yang dikerjakan.

Pada soal kedua, ada 29 orang memahami masalah $100 \%$, ada 4 orang memahami masalah $66,67 \%$, ada 2 orang memahami masalah $33,33 \%$, dan ada 1 orang tidak memahami masalah sama sekali. Ada 12 orang yang mampu merencanakan masalah $100 \%$, ada 22 orang yang mampu merencanakan penyelesaian $50 \%$, dan ada 2 orang yang tidak mampu merencanakan masalah sama sekali. Hanya 9 orang yang mampu melaksanakan penyelesaian $100 \%$, ada 13 orang yang mampu melaksanakan penyelesaian $66,67 \%$, ada 10 orang yang mampu melaksanakan penyelesaian $33,33 \%$, dan ada 4 orang yang tidak mampu melaksanakan penyelesaian sama sekali. Ada 10 orang yang melakukan $100 \%$ pengecekan terhadap semua langkah yang dikerjakan, hanya 5 orang yang melakukan 50\% pengecekan terhadap semua langkah yang dikerjakan, bahkan ada 21 orang yang sama sekali tidak melakukan pengecekan terhadap semua langkah yang dikerjakan.

Pada soal ketiga, ada 16 orang memahami masalah $100 \%$, ada 15 orang memahami masalah $66,67 \%$, ada 1 orang memahami masalah $33,33 \%$, dan ada 4 orang tidak memahami masalah sama sekali. Ada 16 orang yang mampu merencanakan masalah $100 \%$, ada 14 orang yang mampu merencanakan penyelesaian $50 \%$, dan ada 6 orang yang tidak mampu merencanakan masalah sama sekali. Hanya 7 orang yang mampu melaksanakan penyelesaian 100\%, ada 18 orang yang mampu melaksanakan penyelesaian $66,67 \%$, ada 4 orang yang mampu melaksanakan penyelesaian $33,33 \%$, dan ada 7 orang yang tidak mampu melaksanakan penyelesaian sama sekali. Hanya 2 orang yang melakukan 100\% pengecekan terhadap semua langkah yang dikerjakan, hanya 9 orang yang melakukan $50 \%$ pengecekan terhadap semua langkah yang dikerjakan, bahkan ada 25 orang yang sama sekali tidak melakukan pengecekan terhadap semua langkah yang dikerjakan.

Tingkat kemampuan pemecahan masalah matematik siswa di kelas kontrol tidak ada yang mendapat kriteria "kemampuan sangat tinggi", tidak ada yang mendapat kriteria "kemampuan tinggi", kriteria "kemampuan sedang" ada sebanyak 7 orang, kriteria "kemampuan rendah" ada sebanyak 10 orang, dan kriteria "kemampuan sangat rendah" ada 19 orang.

Hasil tes kemampuan pemecahan masalah matematik siswa kelas eksperimen diperoleh pada soal pertama, ada 27 orang memahami masalah $100 \%$, ada 7 orang memahami masalah $66,67 \%$, ada 2 orang memahami masalah $33,33 \%$, dan tidak ada orang yang tidak memahami masalah sama sekali. Ada 30 orang yang mampu merencanakan masalah $100 \%$, ada 6 orang yang mampu merencanakan penyelesaian

Elfrida Monika Yulianti Sinaga, Ani Minarn. The Effect Problem-Based Learning Model on ProblemSolvin Ability Mathematics Student Class IX SMP Negeri 6 Medan. Jurnal Inspiratif, Vol 3. No. 3 Desember 2017. 
$50 \%$, bahkan tidak ada orang yang tidak mampu merencanakan masalah sama sekali. Ada 29 orang yang mampu melaksanakan penyelesaian $100 \%$, ada 6 orang yang mampu melaksanakan penyelesaian $66,67 \%$, hanya 1 orang yang mampu melaksanakan penyelesaian $33,33 \%$, bahkan tidak ada orang yang tidak mampu melaksanakan penyelesaian sama sekali. Ada 15 orang yang melakukan $100 \%$ pengecekan terhadap semua langkah yang dikerjakan, ada 17 orang yang melakukan $50 \%$ pengecekan terhadap semua langkah yang dikerjakan, ada 4 orang yang sama sekali tidak melakukan pengecekan terhadap semua langkah yang dikerjakan.

Pada soal kedua, ada 35 orang memahami masalah $100 \%$, ada 1 orang memahami masalah $66,67 \%$, dan tidak ada orang yang tidak memahami masalah sama sekali. Ada 17 orang yang mampu merencanakan masalah $100 \%$, ada 19 orang yang mampu merencanakan penyelesaian $50 \%$, bahkan tidak ada orang yang tidak mampu merencanakan masalah sama sekali. Ada 13 orang yang mampu melaksanakan penyelesaian $100 \%$, ada 20 orang yang mampu melaksanakan penyelesaian $66,67 \%$, ada 3 orang yang mampu melaksanakan penyelesaian $33,33 \%$, dan tidak ada orang yang tidak mampu melaksanakan penyelesaian sama sekali. Ada 15 orang yang melakukan $100 \%$ pengecekan terhadap semua langkah yang dikerjakan, ada 10 orang yang melakukan $50 \%$ pengecekan terhadap semua langkah yang dikerjakan, dan ada 11 orang yang sama sekali tidak melakukan pengecekan terhadap semua langkah yang dikerjakan.

Pada soal ketiga, ada 6 orang memahami masalah $100 \%$, ada 27 orang memahami masalah $66,67 \%$, ada 3 orang memahami masalah $33,33 \%$, dan tidak ada orang tidak memahami masalah sama sekali. Ada 12 orang yang mampu merencanakan masalah $100 \%$, ada 22 orang yang mampu merencanakan penyelesaian $50 \%$, dan ada 2 orang yang tidak mampu merencanakan masalah sama sekali. Ada 14 orang yang mampu melaksanakan penyelesaian $100 \%$, ada 9 orang yang mampu melaksanakan penyelesaian $66,67 \%$, ada 9 orang yang mampu melaksanakan penyelesaian 33,33\%, dan hanya 4 orang yang tidak mampu melaksanakan penyelesaian sama sekali. Ada 13 orang yang melakukan $100 \%$ pengecekan terhadap semua langkah yang dikerjakan, ada 6 orang yang melakukan 50\% pengecekan terhadap semua langkah yang dikerjakan, dan ada 17 orang yang sama sekali tidak melakukan pengecekan terhadap semua langkah yang dikerjakan.

Tingkat kemampuan pemecahan masalah matematik siswa secara kuantitatif di kelas eksperimen yang mendapat kriteria "kemampuan sangat tinggi" ada sebanyak 5 orang, yang mendapat kriteria "kemampuan tinggi" ada sebanyak 10 orang, yang mendapat kriteria "kemampuan sedang" ada sebanyak 15 orang, yang mendapat kriteria "kemampuan rendah" ada sebanyak 3 orang, yang mendapat kriteria "kemampuan sangat rendah" ada sebanyak 3 orang. Sebanyak 30 siswa $(83,33 \%)$ sudah berada pada kategori sedang, tinggi, dan sangat tinggi.

Temuan di atas serupa dengan hasil penelitian yang dilakukan Simamora, dkk. (2017), bahwa penerapan model pembelajaran berbasis masalah dapat meningkatkan aktivitas belajar dan kemampuan pemecahan masalah matematik siswa di kelas VIIB SMP Negeri 3 Medan. Begitu juga dengan Amalia, dkk. (2017), menunjukkan bahwa nilai ratarata siswa yang diajar dengan menggunakan pembelajaran berbasis masalah lebih tinggi dari siswa yang diajar dengan menggunakan model pembelajaran konvensional. Dengan menggunakan uji-t, kita tahu bahwa nilai signifikan kurang dari 0,05 artinya pembelajaran dengan menggunakan model pembelajaran berbasis masalah efektif dalam memperbaiki kemampuan pemecahan masalah matematik siswa.

Berdasarkan temuan dan hasil penelitian di atas maka dapat diungkapkan bahwa terdapat pengaruh yang signifikan model pembelajaran berbasis masalah terhadap kemampuan pemecahan masalah matematik siswa. Hal ini dapat dilihat dari rata-rata nilai kemampuan pemecahan masalah matematik siswa yang diajar melalui pembelajaran berbasis masalah lebih tinggi daripada ratarata kemampuan pemecahan masalah

Elfrida Monika Yulianti Sinaga, Ani Minarn. The Effect Problem-Based Learning Model on ProblemSolvin Ability Mathematics Student Class IX SMP Negeri 6 Medan. Jurnal Inspiratif, Vol 3. No. 3 Desember 2017. 
matematik siswa yang diajar melalui pembelajaran konvensional yaitu model pembelajaran langsung.

\section{KESIMPULAN DAN SARAN}

Berdasarkan analisis terhadap data penelitian dan pembahasan yang telah diuraikan pada bab terdahulu, maka dapat disimpulkan bahwa terdapat pengaruh yang signifikan model pembelajaran berbasis masalah terhadap kemampuan pemecahan masalah matematik siswa kelas IX SMP Negeri 6 Medan. Rata-rata kemampuan pemecahan masalah matematik siswa di kelas kontrol sebesar 51,83, sedangkan rata-rata kemampuan pemecahan masalah matematik siswa di kelas eksperimen sebesar 75,50.

Berdasarkan hasil penelitian ini, maka saran yang dapat diajukan antara lain sebagai berikut:

1. Guru matematika disarankan menggunakan model pembelajaran berbasis masalah sebagai salah satu alternatif dalam kegiatan pembelajaran serta model pembelajaran yang diharapkan dapat meningkatkan kemampuan pemecahan masalah matematik siswa.

2. Guru matematika harus benar-benar menjalankan sintaks model pembelajaran berbasis masalah agar tujuan pembelajaran tercapai.

3. Calon peneliti dapat mempertimbangkan untuk menerapkan pembelajaran berbasis masalah ini dalam penelitiannya, diharapkan untuk membekali kemampuan agar dapat menerapkan model pembelajaran berbasis masalah sehingga lebih bijak dalam mengolah kelas, baik dalam hal menerapkan model, menertibkan siswa maupun mengalokasikan waktu agar mendapatkan hasil yang lebih baik dan dapat sebagai bahan perbandingan.

\section{DAFTAR PUSTAKA}

Agustina, D., Musdi, E., Fauzan, A., (2014), Penerapan Strategi Pemecahan Masalah Untuk Meningkatkan Kemampuan Pemecahan Masalah Matematis Siswa Kelas VIII SMP Negeri 7 Medan, Jurnal Pendidikan Matematika 3: 20-24

Amalia, E., Surya, E., Syahputra, E., (2017), The Effectiveness of Using Problem Based Learning (PBL) in Mathematics Problem Solving Ability for Junior High School Students, IJARIIE, 3 (2): 34023406.

Cochran, W.G., (1991), Teknik Pengambilan Sampel, UI-Press, Jakarta

Huda, M., (2014), Model-Model Pengajaran dan Pembelajaran, Pustaka Pelajar, Yogyakarta.

Hudojo, H., (2005), Pengembangan Kurikulum dan Pembelajaran Matematika, Universitas Negeri Malang, Malang

NCTM, (2000). Principles and Standards For School Mathematics, USA, NCTM.

Simamora, R.E., Sidabutar, D.R., Surya, E., (2017), Improving Learning Activity And Students' Problem Solving Skill through Problem Based Learning (PBL) in Junior High School, International Journal of Sciences: Basics and Applied Research 33: 321-331

Sulistyani, N., Retnawati, H., (2015), Pengembangan Perangkat Pembelajaran Bangun Ruang di SMP dengan Pendekatan Problem-Based Learning, Jurnal Riset Pendidikan Matematika 2: 197-210.

Surya E. 2013. Analisis Pemetaan dan Pengembangan Model Pembelajaran Matematika SMA di Kabupaten Tapteng dan Kota Sibolga Sumatera Utara. Jurnal

Elfrida Monika Yulianti Sinaga, Ani Minarn. The Effect Problem-Based Learning Model on ProblemSolvin Ability Mathematics Student Class IX SMP Negeri 6 Medan. Jurnal Inspiratif, Vol 3. No. 3 Desember 2017. 
Pendidikan Matematika Paradikma, 6(1), 75-88.

Surya, E. Putri, F.A. and Mukhtar. 2017. Improving Mahematical Problem Solving
Ability and Self-Confidence of High School Students Through Contextual Learning Model. Indonesian Mathematical Society Journal on Mathematics Education, 8(1), 85-94. 
